\title{
AN EVALUATION OF THE INDONESIAN LAW AND POLICY ON SMALL-SCALE FISHERIES*
}

\author{
Melda Kamil Ariadno** \\ Fitri Amelina***
}

\begin{abstract}
Fisheries play an important role in food security, especially in Indonesia. Two-thirds of the land area is covered by sea and its coastal community is the largest one among the Indonesian communities. Data obtained from the Ministry of Fisheries and Marine Affairs in 2011 shows that 95 per cent of the operators in the Indonesian fisheries sub-sector operated on the small-scale and 42 per cent of them were women. Small-scale fisheries provide a great contribution to the food security of Indonesia and the world, either in the context of fulfilling animal protein needs or providing a basis for the local, national, and international-scale trade in fisheries products. The Indonesian fishing community contributes to the 90 per cent total amount of world fishers, of which half are women (FAO, 2012). To improve this small-scale fishing, the Food and Agriculture Organization (FAO) has initiated the adoption of 'International Guidelines for Securing Sustainable Small-Scale Fisheries.' It is still in negotiation regarding the main principles that are to be implemented by states in securing the sustainability of small-scale fisheries and figuring out the solutions that need to be taken by Indonesia to improve the living standard of the small-scale fisherman/woman. The article aims to provide problems identification, regulations assessment, and recommendations on small-scale fisheries in Indonesia.
\end{abstract}

Keywords: Small-scale fisheries, international regulation, Indonesia.

DOI: http://dx.doi.org/10.4314/jsdlp.v7i2.3

* This article is the outcome of the research funded by the University of Indonesia on a giveaway scheme (Small Scale Fisheries) led by Melda Kamil Ariadno alongside with the research team members, namely, Mutiara Hikmah, Sammira Assovie, Fitri Amelina and Miftahul Khairi.

** Professor of International Law, Department of International Law, Faculty of Law, Universitas Indonesia. Director of the Center for International Law Studies and Editor-in-Chief of the Indonesian Journal of International Law, Faculty of Law Universitas Indonesia.

$* * *$ Junior Researcher on Center for International Law Studies, Faculty of Law Universitas Indonesia. 


\section{SMALL-SCALE FISHERIES IN INDONESIA}

As the world's largest Archipelagic State with two-thirds of its land area covered by the sea, the high potential from its sea and that the majority of Indonesian people are coastal communities living as fishermen are not surprising. ${ }^{1}$ The potential of fisheries owned by the fishermen is the source of state revenue, besides it is also the source of livelihood for most people in the coastal areas, especially fishermen/ women. ${ }^{2}$ Generally, fishing in Indonesia is still dominated by smallscale fishing businesses. Indeed, only 15 per cent of the fishing businesses in the country are classified as large-scale, the remaining 85 per cent are all small-scale businesses. ${ }^{3}$ Based on data obtained from the Ministry of Maritime Affairs and Fisheries in 2011, 95 per cent of Indonesians are small-scale operators in the fishing business and 42 per cent of them are women. ${ }^{4}$ Small-scale fisheries make a significant contribution to the food security of Indonesia and the world and provide a great deal of animal protein needs. They also provide a viable means of trade at the local, national and international levels.

Observably the marine potential of Indonesia has not been used optimally. There are problems in the industry which could be ascribed to some reasons. Among these are that ${ }^{5}$ most fishermen still use traditional fishing methods with the socio-cultural characteristics that do not keep up with improvements in the sector; the fishing fleets structure is still dominated by small-scale/traditional methods with low science and technology capabilities; and there is a gap in the level of utilization of fish stocks in the region with other sea waters. Also, there are many Illegal, Unregulated, and Unreported (IUU) fishing

1 Pusat Penelitian dan Pengembangan Geologi Kelautan, 'Morfologi Dasar Laut Indonesia' < http://www.mgi.esdm.go.id/content/morfologi-dasar-lautindonesia $>$ accessed 29 May 2016.

2 Markus Sembiring,'Analisis Keberlanjutan Perikanan Tangkap Skala Kecil' (2012) <http://diskanla.langkatkab.go.id/berita/artikel/25-analisis-keberlanjutanperikanan-tangkap-skala-kecil-di-kablangkat.html> accessed 29 May 2016

3 M. Hermawan, 'Keberlanjutan Perikanan Tangkap Skala Kecil (Kasus Perikanan Pantai di Serang dan Tegal' (Disertasi S3 Sekolah Pascasarjana IPB, 2006 Bogor).

4 Indonesian Ministry of Marine and Fisheries < http://kkp.go.id/> accessed 29 May 2016.

5 Ir. Sugeng Hari Wisudo M.Si dan Iin Solihin, S.Pi M.Si. (Indonesian Ministry of Marine and Fisheries 2008) Data received from field study and Directorate of Marines and Fisheries from 2005. 
practices and over-fishing ${ }^{6}$ that occur due to weak law enforcement at sea; inadequate infrastructure to support fisheries; environmental degradation of the marine ecosystem, such as the destruction of mangrove forests, coral reefs, and sea grass beds, which are actually the natural habitat for fish and other marine organisms to use as their spawning ground, feeding ground, or nursery grounds; and the poor ability of the handling and processing of fisheries products, mainly by traditional business that suits consumer's tastes and international standardization of product quality (such as the Hazard Analysis Critical Control Point/HACCP, sanitation requirements, and others). The subsector is also characterized by low market intelligence which includes the mastery of information on competitors, market segmentation, and preference of the consumer about the type and quality of fisheries commodities; inadequate economic infrastructure and the means of transportation and communication systems to support the distribution or delivery of fisheries products from producers to consumers in a timely manner, especially outside Java and Bali. ${ }^{7}$

The article aims to identify the problems Indonesia faces on smallscale fishing, assess the national regulations in relation to its conformity with the international legal framework, and proffer recommendations for achieving sustainability in the small-scale fishing in the country. The article is divided into four sections. Following the introduction, the second section focuses on the empowerment of small-scale fisheries in Indonesia. The third section analyses the level of conformity of national regulations with the international legal framework. The final section provides the conclusion and recommendations.

6 Over-fishing or excessive fish harvesting puts the resources stock (on average) below the number to generate maximum potential production in the long term. Being overfished is also often defined as the harvesting rate, which exceeds the rate of the speed that the fish needs to recover its population. Kajian Hukum dalam Rangka Memerangi Kegiatan IUU 'Fishing di Indonesia' (Ministry of Marine and Fisheries, 26 May 2016 ) < http://balitbangkp.kkp.go.id/petatematik/kajianhukum-dalam-rangka-memerangi-kegiatan-iuu-fishing-di-indonesia/\# > accessed on 29 May 2016.

7 Husni Mangga Berani, 'Pemikiran Percepatan Pembangunan Perikanan Tagkap Melalui Gerakan Nasional' (2004) < http://tumoutou.net/702_07134/ husni_mb.pdf> accessed 7 September 2014. 


\section{EMPOWERMENT PROGRAMME ON SMALL-SCALE FISHERIES IN INDONESIA}

The data of Central Bureau of Statistics (Biro Pusat Statistik) shows that the number of poor people in Indonesia in 2011 was 31.02 million people (PODES, BPS), of which 25.14 per cent, or, 7.87 million people, are a coastal community. Also, there are 2,755,178 fishermen and women more than 90 per cent of which are small-scale operators. These small-scale operators who face difficulties in their livelihood are mainly those who fish at sea.

In accordance with the Presidential Decree No. 5 of 2010 concerning the Medium Term National Development Plan (Rencana Pembangunan Jangka Menengah Nasional) (2010-2014), the Directorate General of Fisheries has set a programme related directly to marine and fisheries development. This 'Development and Management Fisheries Programme' is to support national targets for marine and fisheries development mandated by the Directorate General of Fisheries, which is also to support key performance indicators (Indikator Kinerja Utama). The indicators are: increasing the volume and value of fisheries production, increasing the income of fishers, and increasing the exchange value of the fishing community.

The problems arising from this plan are also related to the decreasing productivity of the Indonesian fishing community. Three factors are thought to be responsible for this decreasing productivity. ${ }^{8}$ The first is that the relatively large number of fishermen and women keeps increasing every year, while the available potential fishing resources remains relatively constant in numbers or even tends to be degraded. Therefore, it is necessary to streamline the number of people engaged in traditional fishing, and the streamlining should be done in a planned, systematic and integrated way. Of course, the policy will run into significant obstacles, especially because most operators depend on their traditional fishing business as the only means of earning a livelihood. Besides, fishing has been a trans-generational occupation for them; so they have become culturally tied to fishing and marine life.

The second factor is the uneven spread of fishermen and women which leads to non-optimal productivity level. Currently, the fishermen

8 Ir. Sugeng Hari Wisudo M.Si dan Iin Solihin, S.Pi M.Si (n 5). 
and women are located in areas of abundant water which are said to have suffered from over fishing. The areas include the Java Sea, the Strait of Malacca, some parts of the Strait of Bali and southern Sulawesi waters. In fact, there are waters that have significant potential, for example, the waters of Western Sumatra and Southern Java, the South China Sea, the Seram Sea, the Banda Sea, and the waters of the Northern of Papua.

The third factor is that the structure of the fishing fleet is still dominated by small-sized fleet (boats without motor and speed boats). Motor-less boats and speed boats are only able to operate in coastal waters. This implies (i) low production due to low productivity; (ii) the possibility of over fishing in coastal waters due to the high density of fish harvesting level; and (iii) the potential conflicts among fishermen because of its high fishing density and the fact that expansions are merely horizontal (i.e., flowing to the waters of the neighbouring regions) and not vertical. The last factor is due to the inclusion of the activities of foreign fishing vessels in the offshore waters/Indonesia's Exclusive Economic Zone. The decline in productivity is understandable considering that the effort is still concentrated in coastal areas with more frequent and intensive fish harvesting, while the potential fish resources in those areas tend to decrease.

Broadly speaking, the government's main programme for improving the living standards of fishers has been established in the Presidential Instruction No. 15 of 2011 concerning Fisherman Protection. The first directive on this Presidential Instruction is addressed to several ministries to carry out tasks according to their respective fields to provide welfare, certainty and legal protection for the fishermen who operate vessels in a size of up to 60 gross tonnages (GT). Thus, the Presidential Instruction No. 15 of 2011 is not specifically intended for small-scale fisheries. Instead, it is targeted at fishermen in general, including the small-scale ones. In the middle of the third quarter of 2014, the Ministry of Marine Affairs and Fisheries is preparing the Draft of Government Regulation (Rancangan Peraturan Pemerintah) concerning the Empowerment of Small Fishermen and Small Fish Farmers. ${ }^{9}$

The Presidential Instruction ordered 22 ministers, heads of agencies, the governor as well as the mayor to implement the programme in

9 Republika, 'KKP Siapkan Aturan Khusus Nelayan Kecil' < http://republika.co.id/ berita/koran/ industri/14/08/31/nb5qb8-kkp-siapkan-aturan-khusus-nelayankecil $>$ accessed 4 September 2014. 
accordance with their duties and powers. In general, the programmes in the Presidential are as follows:

a. Facilitating cooperation with banks to finance fishermen;

b. Providing social security and health care for fishermen;

c. Easing capital access to the fishing community;

d. Providing fisheries partnership;

e. Subsidizing fuel.

Prior to the issuance of Presidential Decree No. 15 of 2011, the President issued the Presidential Decree No. 10 of 2011, which established the formation of a working group (Kelompok Kerja) for Fishermen Life Improvement Programme, chaired by the Minister of Maritime Affairs and Fisheries with 11 members, including Minister/ Head of Agencies/Deputy Minister. This working group has run several programmes to improve the lives of fishermen such as:

a. Construction of cheap and affordable housing;

b. Provision of alternative and additional jobs for fishermen's families;

c. Setting of a Minimum Regional Salary (Upah Minimum Kabupaten) and Credit for People's Business (Kredit Usaha Rakyat) Scheme;

d. Construction of solar gas stations;

e. Construction of cold storage;

f. Provision of low-cost public transport;

g. Provision of school facilities and health centres;

h. Provision of banking facilities for the people. ${ }^{10}$

In general, it can be concluded that not all government programmes on a ministerial scale can be applied in all areas. Equitability until now remains an obstacle. Although, it does not mean that there is no achievement at the local government level. The results of field research on Batang, Central Java, show some achievements on a local scale in the area. According to the Chairman of the Association of Indonesian Fishermen (Himpunan Nelayan Seluruh Indonesia - HNSI) Batang, the living standards of small-scale fishermen in Batang have been increasing

10 Indonesian Ministry of Maritime and Fisheries, 'Peningkatan Kehidupan Nelayan (PKN) <www.pupi.kkp.go.id/index.php/peningkatan-kehidupan-nelayan> accessed 17 June 2014. 
in recent years due to improvements in the housing conditions and vehicle ownership. Some fishermen have high consumption life pattern, especially the older fisherman who tend to have high intakes of alcohol. These old fishermen believe that 'money can be obtained again every day from the sea'. Younger fishermen, on the contrary, have a better perspective of life and are, thus, oriented towards diversification. According to the Chairman of HNSI, an effective way to implement programmes that empower fishermen through business diversification is to showcase some 'successful example'.

The next review is carried out in the town of Tarakan, North Kalimantan, where the development of marine and fisheries sub-sector has good development prospects. The newly managed potential at this time amounted to 75.14 per cent of the total potential with details of fishery production at 8,560 tons/year, leaving about 5,000 tons in the sea. ${ }^{11}$ Thus, regarding natural resources, the fisheries sub-sector in Tarakan has high potential although, not all government programmes can be implemented optimally. DKP Tarakan continually strives to improve on its services to the small-scale fishermen and women, especially through the ownership of Fisherman Card, PUMP, enhancement of KUB Fishermen's functions and equalization of subsidized fuel. Those programmes are becoming the focus of DKP Tarakan.

Speaking about the implementation problems of government programmes, which are aimed at empowering small-scale fishermen in Indonesia, the first problem lies in inequality. Not all planned programmes can run smoothly in every area. Some of the factors affecting the smooth running of the programmes include inadequate human resources; differences in the characteristics of each region which affect the mode of fishing gear required, types of available in each region, and the marine geographical structure of each region. Other factors are the level of responsiveness of the local Department of Marine and Fisheries. These factors greatly affect the implementation of smallscale fisheries' development programmes, resulting in the inability of the small fishermen and women to prosper from their work in the region. This is a contradiction from the expected profile of Indonesia as a maritime country that should have a very big marine potential that would improve the livelihood of the coastal communities, especially small-scale fishermen and women.

11 Bureau of Maritime and Fisheries, Annual Report of 2012. 
At this moment, the FAO is preparing the International Guidelines for Securing Sustainable Small-Scale Fisheries ('FAO Guidelines'), which is currently at the negotiation stage. ${ }^{12}$ These guidelines are intended as 'voluntary international document' expected to be adopted by the FAO Member States to reformulate its policy regarding the management of small fishermen in order to conform to the principles of sustainable fisheries. Indonesia needs to examine this document in order to make meaningful contributions at the negotiation forums so that the interests of the Indonesian small fishermen are not jeopardized and the small fishermen can continue to carry out their activities without sacrificing sustainability of their trade.

\section{CONFORMITY OF LEGAL INSTRUMENTS TO IMPROVE THE LIVING STANDARD OF SMALL-SCALE FISHERMEN}

A Code of Conduct for Responsible Fisheries ('CCRF') was adopted at the Food and Agriculture Organization Conference held in Rome in 1995. This CCRF was expected contribute to national and international regulation making to improve sustainable development in small-scale fishing from the economic, social, and environmental perspectives. The CCRF requires the state to cover the small-scale fisherman with legal and institutional protection; provide guidance for implementing international treaties or other legal instrument; offer technical and financial cooperation in the conservation of resources and fisheries management; and provide quality improvement and food security through the fishing business. ${ }^{13}$

The FAO guidelines were created to support small-scale fishing and to give support to the national and global effort in mitigating hunger and poverty. The guidelines also involve small-scale fishermen and women in decision making as well as in gaining advantage and fulfilling their rights in the context of sustainable development. ${ }^{14}$ Furthermore, the FAO Guidelines aim to adopt good recommendations, implement

12 The first and second negotiations were held at the FAO Headquarters in Rome, in 2013 and 2014.

13 Food and Agriculture Organization of the United Nations, Code of Conduct for Responsible Fisheries 1995, Article 2.

14 Food and Agriculture Organization of the United Nations, International Guidelines for Securing Sustainable Small Scale Fisheries, 2012, 3. 
sound principles and criteria that will enhance the sustainable development of small-scale fishing. ${ }^{15}$ The FAO Guidelines ensure access to resources for the small-scale fishing community to increase their standard of living both on sea and on land, as well as to ensure that they enjoy their fundamental rights in respect of public housing and in the processing and marketing of their goods.

The core aims of the FAO Guidelines are to recognize, support, improve and sustain the important contribution of small-scale fishing to the national and global efforts towards the elimination of hunger and poverty. The Guidelines support responsible and sustainable fisheries policy and economic development in the interest of present and future generations. The Guidelines place a strong emphasis on the small-scale fisherman, fish worker, and all those related activities of the marginalized groups within the fisheries community. Some highlights of the Guidelines are:

1. Recognition of the important role of small-scale fisheries;

2. Eradication of hunger and poverty;

3. Recognition of government's role in social and economic development;

4. Creation of a sustainable development pathway for small-scale fishing;

5. Protection of the interest of fishermen and all fish workers;

6. Protection of human rights.

Table 1 shows the level of conformity between national and international legal instruments regarding small-scale fishing.

Based on this table, Indonesia's national regulations are in accordance with international regulations on small-scale fishing. The Indonesian government has given some attention to the small-scale fisheries sector because it is a maritime country with 90 per cent smallscale fishermen. The implementation of empowerment policy and improvement of the welfare of small-scale fishermen in Indonesia is quite comprehensive, although there are still some issues that need to be addressed. Among such issues are the collection of small-scale fishermen and vessels under 5 GT, which is not yet in order and wellintegrated; the need for the diversification of fishing effort; more protection of fisherwomen; and more policy-oriented research 
programme. On research development, it can be said that Indonesia has moved a step forward because it is oriented on the formation of public policy and not only on resource utilization.

Table 1. The Conformity of National and International Legal Instruments on Small-Scale Fishing

\begin{tabular}{|c|c|c|c|}
\hline No & Regulation & $\begin{array}{l}\text { International } \\
\text { Instrument }\end{array}$ & National Instrument \\
\hline 1 & $\begin{array}{l}\text { Definition of } \\
\text { small-scale } \\
\text { fishermen }\end{array}$ & $\begin{array}{l}\text { There is no universal } \\
\text { definition of small-scale } \\
\text { fishermen in any } \\
\text { international instrument. } \\
\text { During the negotiation on } \\
\text { the FAO Guidelines in } \\
\text { February 2014, the matter } \\
\text { was referred to each } \\
\text { country to determine the } \\
\text { limits of and criteria for } \\
\text { small-scale fishermen. In } \\
\text { its proposition at that } \\
\text { time, Indonesia defined } \\
\text { small-scale fishermen as } \\
\text { operators with limited } \\
\text { operational capital, simple } \\
\text { fishing gear, limited } \\
\text { expertise, living at the } \\
\text { margin of economic } \\
\text { subsistence, marketing } \\
\text { their catches, and having } \\
\text { local knowledge of their } \\
\text { environment. }{ }^{16} \\
\text { The Member States, } \\
\text { however, rejected these } \\
\text { criteria }{ }^{17} \text { because of the }\end{array}$ & $\begin{array}{l}\text { Article } 1 \text { paragraph } 11 \text { of } \\
\text { Law No. } 31 \text { of } 2004 \text { in } \\
\text { conjunction with Law No. } 45 \\
\text { of } 2009 \text { on Fisheries } \\
\text { ('Fisheries Act') does provide } \\
\text { a definition of 'small-scale } \\
\text { fishermen', that is, fishermen } \\
\text { who operate fishing boats } \\
\text { under } 5 \text { GT. The definition } \\
\text { of Small-scale Fishermen in } \\
\text { the Fisheries Act is deemed } \\
\text { to be no longer fit with the } \\
\text { existing development. }{ }^{18} \text { It } \\
\text { would be better if 'Small } \\
\text { Fishermen' is also seen from } \\
\text { the turnover and capital for } \\
\text { micro Business, }{ }^{19} \text { as } \\
\text { stipulated in Law No. } 20 \text { of } \\
2008 \text { on Micro, Small and } \\
\text { Medium Enterprises ('SME } \\
\text { Law') which has a net } \\
\text { wealth of Rp } 50,000,000.00 \\
\text { (fifty million rupiahs) at } \\
\text { most, excluding land and } \\
\text { buildings; or having annual } \\
\text { sales of Rp } 300,000,000.00\end{array}$ \\
\hline
\end{tabular}

16 Negotiation stance of delegate of the Republic of Indonesia dated 14 May 2013.

17 Resumed Session of the Technical Consultation on International Guidelines on Securing Sustainable Small Scale Fisheries (3-7 February 2014); Interview with Mrs. Trukan Sri Bahukeling, Directorate of Capture Fisheries, Indonesian Ministry of Marine and Resources on 25 June 2014.

18 Interview with Mr. M. Bilahmar, Head of Indonesian Fishermen Society/ Himpunan Nelayan Seluruh Indonesia (HNSI) on 18 June 2014.

19 Law No. 20 of 2008 on Mini, Small and Medium Enterprises, Small Enterprises is productive business owned by individual and/or individual business entity, which fulfilled the criteria of Small Enterprises as, sets out in this Law. 
Table 1 (cont'd). The Conformity of National and International Legal Instruments on Small-Scale Fishing

\begin{tabular}{|c|c|c|c|}
\hline & & $\begin{array}{l}\text { different levels of } \\
\text { prosperity between the } \\
\text { developed and developing } \\
\text { countries. Hence, it will be } \\
\text { very difficult to determine } \\
\text { universal criteria that } \\
\text { could be applied to all } \\
\text { states. }\end{array}$ & $\begin{array}{l}\text { (three hundred million } \\
\text { rupiahs). }{ }^{20}\end{array}$ \\
\hline 2 & $\begin{array}{l}\text { Empowerment } \\
\text { of small-scale } \\
\text { fishermen }\end{array}$ & $\begin{array}{l}\text { Article } 6.18 \text { CCRF } \\
\text { regulates the protection of } \\
\text { the rights of small-scale } \\
\text { fishermen to obtain } \\
\text { 'secure and just } \\
\text { livelihood'. Furthermore, } \\
\text { the FAO Guidelines, which } \\
\text { advocate for and } \\
\text { complement the CCRF, do } \\
\text { not specifically regulate } \\
\text { small-scale fishermen's } \\
\text { empowerment } \\
\text { programme. The FAO } \\
\text { Guidelines emphasize the } \\
\text { protection of the } \\
\text { fishermen's rights, which } \\
\text { are protected in the } \\
\text { Universal Declaration of } \\
\text { Human Rights and the } \\
\text { International Covenant on } \\
\text { Economic, Social, and } \\
\text { Cultural Rights. }\end{array}$ & $\begin{array}{l}\text { Some laws grant fisheries } \\
\text { subsidies, especially for } \\
\text { small-scale fishermen in } \\
\text { Indonesia, namely: } \\
\text { 1. Article } 60 \text { and Article } 63 \\
\text { of the Fisheries Act } \\
\text { concerning credit scheme for } \\
\text { small fishermen and } \\
\text { development of fishermen. } \\
\text { 2. Presidential Decree No. } \\
\text { 10 of } 2011 \text {; in which } \\
\text { President Susilo Bambang } \\
\text { Yudhoyonon ordered the } \\
\text { creation of a Working Group } \\
\text { on Fishermen's Life } \\
\text { Improvement which is } \\
\text { chaired by the Minister of } \\
\text { Maritime and Fisheries with } \\
\text { 11 other members, } \\
\text { including Ministers/Deputy } \\
\text { Ministers. This working } \\
\text { group is a part of the } \\
\text { coordination team for the } \\
\text { improvement and expansion } \\
\text { of pro-people programmes. } \\
\text { The task is to formulate } \\
\text { national policies and action } \\
\text { plans, set up a national } \\
\text { action plan on the } \\
\text { improvement and expansion } \\
\text { of pro-people programmes }\end{array}$ \\
\hline
\end{tabular}

20 Indonesia, Law No. 31 of 2004 jo Law Number 45 of 2009 on Fisheries, Article 60, Article 63.

21 Indonesia, Law No. 31 of 2004 jo Law Number 45 of 2009 on Fisheries, Article 60, Article 63. 
Table 1 (cont'd). The Conformity of National and International Legal Instruments on Small-Scale Fishing

and ensure its

implementation. ${ }^{22}$

3. Presidential Instruction

No. 15 of 2011 on the

Protection of Fishermen mandates:

a. Facilitate cooperation with banks to finance

fishermen;

b. The provision of social security and health care of fishermen;

c. The easing of capital for those in need;

d. The provision of fisheries partnership;

e. The provision of subsidized fuel.

Programmes designed

to improve the

livelihood of small-scale fishermen:

1. Programme on the Prevention of Poverty on Fisherman (PKN);

2. Fishermen Protection;

3. Fishermen Card;

4. PUMP (capital grants for fishermen);

5. Credit Schemes with subsidized interest payments in cooperation with banks (KUR-KKPE);

6. Certification on fishermen's land or SeHAT (with a certified land. This would ease the allocation of security rights for loans obtained by the fishermen);

7. Establishment of Fishermen's Group (Business Group) to strengthen the fishermen's guild.

22 Indonesia, Presidential Decree No. 10 of 2011 on Coordination Team for Development and Expansion of Pro-Citizen Programme. 
Table 1 (cont'd). The Conformity of National and International Legal Instruments on Small-Scale Fishing

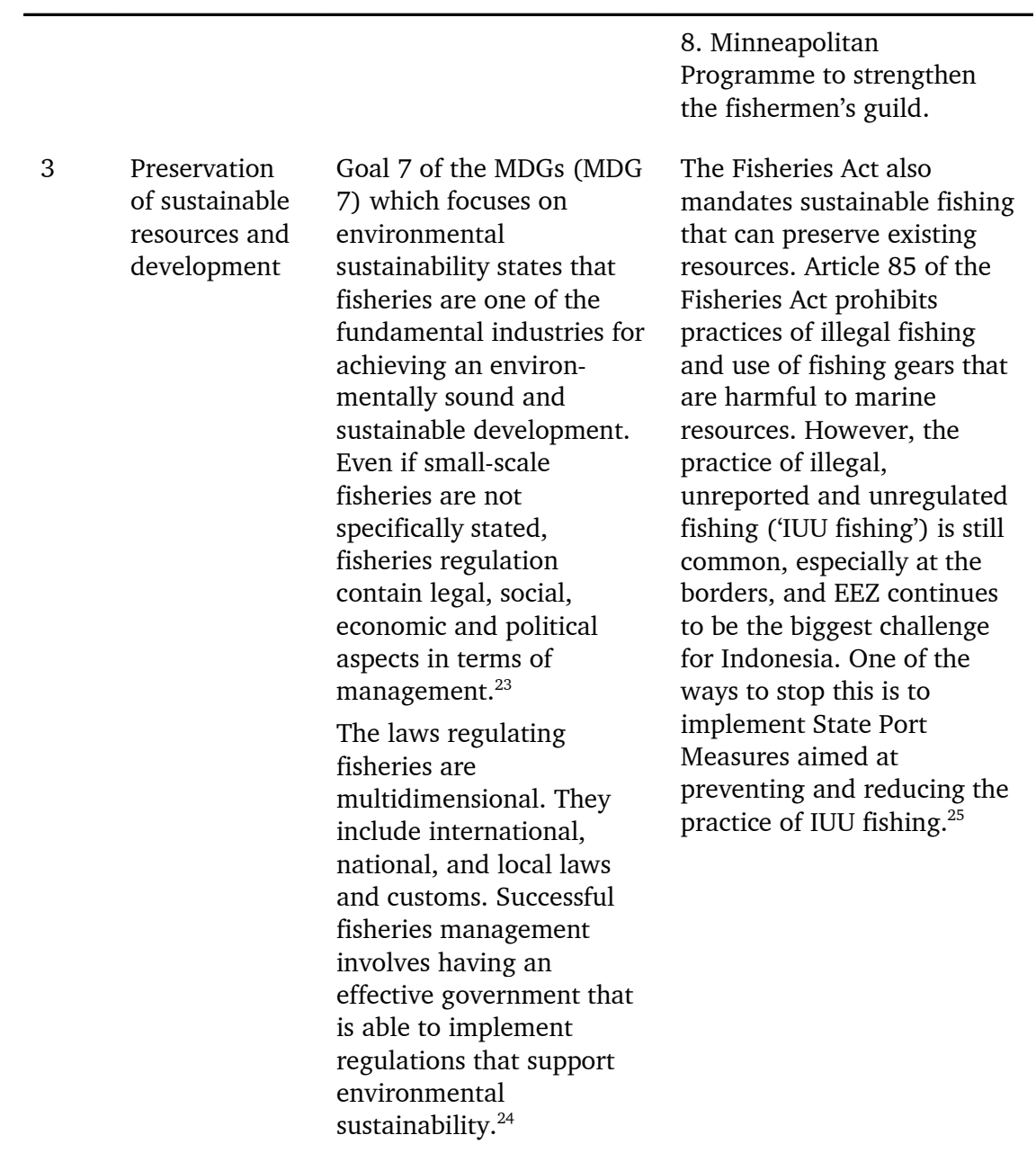

23 A. A. Rosenberg, J. H. Swasey, and M. Bowman, 'Rebuilding US Fisheries: Progress and Problems' (2006) Frontiers in Ecology and the Environment 4(6) 303308.

24 United Nations Development Group, Thematic Papers on the Millennium Development Goals.

25 Interview with Mr M. Bilahmar (n 18). 
Table 1 (cont'd). The Conformity of National and International Legal Instruments on Small-Scale Fishing

\begin{tabular}{|c|c|c|c|}
\hline 4 & $\begin{array}{l}\text { Sustainable } \\
\text { fisheries }\end{array}$ & $\begin{array}{l}\text { Article } 11.3 \text { of FAO } \\
\text { Guidelines, Context of } \\
\text { Food Security and Poverty } \\
\text { Eradication, canvasses an } \\
\text { objective and integrated } \\
\text { regulation and/or policy } \\
\text { on small-scale fisheries } \\
\text { that allows various sectors } \\
\text { to collaborate to } \\
\text { accommodate the needs of } \\
\text { small-scale fishermen. } \\
\text { These regulations will } \\
\text { have long-term impacts in } \\
\text { achieving sustainable } \\
\text { fisheries. }\end{array}$ & $\begin{array}{l}\text { The Ministry of Marine } \\
\text { Affairs and Fisheries has a } \\
\text { monitoring and evaluation } \\
\text { programme by conducting } \\
\text { visits to the region for direct } \\
\text { observation. }{ }^{27}\end{array}$ \\
\hline 5 & $\begin{array}{l}\text { Social } \\
\text { development }\end{array}$ & $\begin{array}{l}\text { In Article 6.3., the } \\
\text { IGSSSSF } \\
\text { encourages the Member } \\
\text { States to facilitate small- } \\
\text { scale fisheries } \\
\text { communities in gaining } \\
\text { access to education, health } \\
\text { and social security. }\end{array}$ & $\begin{array}{l}\text { Social development efforts } \\
\text { are carried out in } \\
\text { accordance with the } \\
\text { Presidential Decree No. } 10 \\
\text { of 2011, in which the } \\
\text { Ministry of Marine Affairs } \\
\text { and Fisheries liaises with } \\
\text { 11-related ministries, } \\
\text { including the Ministry of } \\
\text { Education and Culture, the } \\
\text { Ministry of Health, etc. } \\
\text { Fishermen's children are } \\
\text { given priority in fisheries } \\
\text { schools. The BPSDM of the } \\
\text { Minister of Marine Affairs } \\
\text { and Fisheries has a policy to } \\
\text { provide special access for } \\
\text { fishermen's children to a } \\
\text { fishery school at the high } \\
\text { school level and the Sekolah } \\
\text { Tinggi Perikanan or Higher } \\
\text { College of Fisheries (D4) } \\
\text { with much less tuition. }{ }^{28}\end{array}$ \\
\hline
\end{tabular}

26 FAO, International Guidelines for Securing Sustainable Small-Scale Fisheries in the Context of Food Security and Poverty Eradication, Article 11.3.

27 Interview with Mrs. Trukan Sri Bahukeling Arief Wirianata (n 17).

28 Interview with Mr. Arief Wirianata, Directorate General of Capture Fisheries (Indonesian Ministry of Maritime Affairs, 18 June 2014). 
Table 1 (cont'd). The Conformity of National and International Legal Instruments on Small-Scale Fishing

\begin{tabular}{|c|c|c|c|}
\hline 6 & $\begin{array}{l}\text { Protection of } \\
\text { tenure right. }\end{array}$ & $\begin{array}{l}\text { In Appendix 2: } \\
\text { International Instruments } \\
\text { Relevant to Small-Scale } \\
\text { Fisheries, FAO Guidelines } \\
\text { refers to the Voluntarily } \\
\text { Guidelines on responsible } \\
\text { Governance of Tenure } \\
\text { Land, Fisheries and } \\
\text { Forests in the Context of } \\
\text { National Food Security } \\
\text { ('Tenure Guidelines') which } \\
\text { aims to give guidelines for } \\
\text { states to optimize the use } \\
\text { of tenure rights of land, } \\
\text { fisheries and forests in } \\
\text { order to achieve food } \\
\text { security. } \\
\text { Protection on tenure } \\
\text { rights of small-scale } \\
\text { fishing communities, } \\
\text { especially with increased } \\
\text { competition from other } \\
\text { users of marine resources. } \\
\text { The provision of access for } \\
\text { small-scale fishermen over } \\
\text { dispute settlements on } \\
\text { tenure rights either } \\
\text { through courts, } \\
\text { administrative agencies, } \\
\text { alternative dispute } \\
\text { resolution or immediate } \\
\text { compensation. }\end{array}$ & $\begin{array}{l}\text { In Indonesia, there are many } \\
\text { disputes on tenure rights } \\
\text { from small-scale fishermen } \\
\text { with the development of } \\
\text { industries such as } \\
\text { mangroves being cut down } \\
\text { for road construction, } \\
\text { housing materials, wood, } \\
\text { cottage and many more. The } \\
\text { mangrove itself is important } \\
\text { for fisheries because of its } \\
\text { function as breeding } \\
\text { grounds. Up till now, tenure } \\
\text { rights are governed in } \\
\text { agriculture, but not } \\
\text { fisheries. }{ }^{31} \text { In contrast, the } \\
\text { Japanese fisheries } \\
\text { cooperative governs tenure } \\
\text { rights. }{ }^{32} \text { Meanwhile, in } \\
\text { Indonesia, there is no special } \\
\text { scheme for small-scale } \\
\text { fishermen regarding dispute } \\
\text { settlement for tenure } \\
\text { rights. }{ }^{33}\end{array}$ \\
\hline 7 & $\begin{array}{l}\text { Protection of } \\
\text { Fisherwomen }\end{array}$ & $\begin{array}{l}\text { Article } 9.1 \text { of the FAO } \\
\text { Guidelines reinforces the } \\
\text { protection of gender } \\
\text { equality and equity based } \\
\text { on the Convention on the }\end{array}$ & $\begin{array}{l}\text { The Law No., } 39 \text { of } 1999 \text { on } \\
\text { Human Rights and Law No. } \\
7 \text { of } 1984 \text { on the Ratification } \\
\text { of the Convention on the } \\
\text { Elimination of All Forms of }\end{array}$ \\
\hline
\end{tabular}

29 Voluntarily Guidelines on responsible Governance of Tenure Land, Fisheries and Forests in the Context of National Food Security, Preface.

30 International Guidelines for Securing Sustainable Small Scale Fisheries in the Context of Food Security and Poverty Eradication, art. 5.10.

31 Interview with Mrs. Trukan Sri Bahukeling (n 17); Mr. Arief Wirianata (n 28).

32 ibid.

33 ibid. 
Table 1 (cont'd). The Conformity of National and International Legal Instruments on Small-Scale Fishing

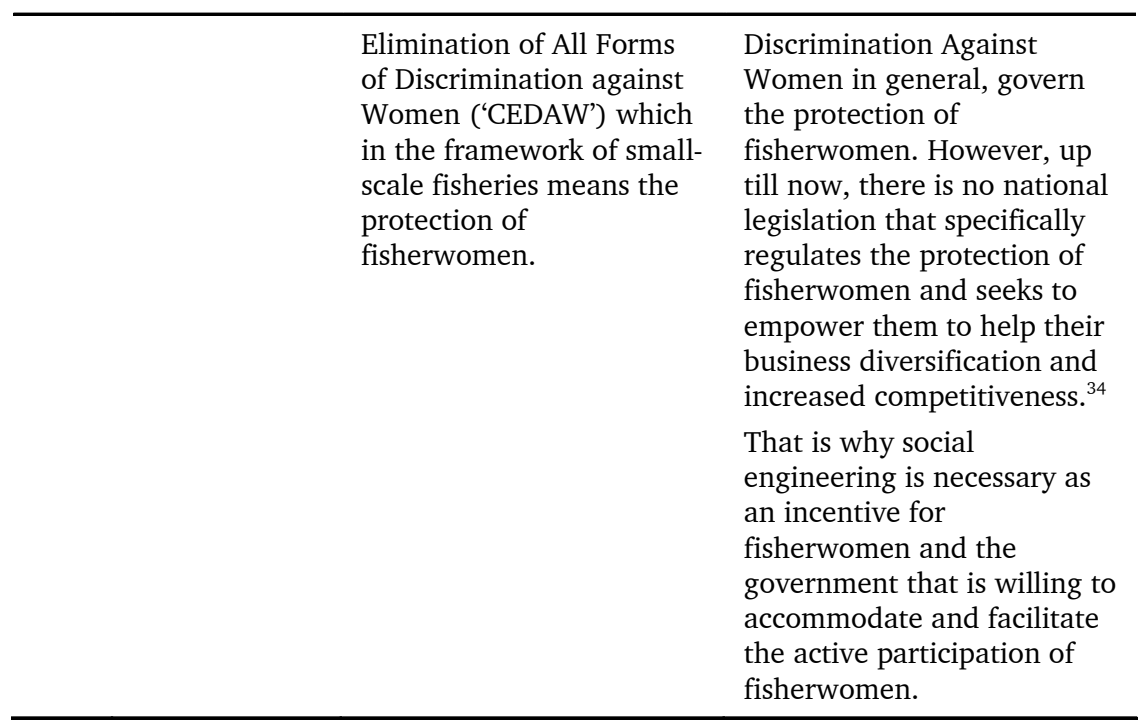

\section{CONCLUSIONS AND RECOMMENDATIONS}

\section{Conclusion}

Indonesian law and policy regarding small-scale fisheries are basically in line with international law the government has protected the interest of small-scale fisherman faithful to the purpose of its programme to improve the welfare of fisherman. One thing that needs to be settled is that aid programme targeted at small-scale fishermen is not widely spread and the different perspectives among local governments regarding what constitute the fishermen's interest.

\section{Recommendations}

Based on these findings, the following recommendations are made on what steps the Indonesian government should take to empower the small-scale fishermen/women and, thereby, achieve sustainability:

1. The government needs to build a common understanding among stakeholders regarding the protection of small-scale

34 Interview with Ms Sutiama, a fisherwoman in Kampung Roban Barat and the head of PPNI Batang Region (PPNI Kabupaten Batang, 16 July 2014). 
fisherman, not only within the government bodies but also among the civil society and the fishermen themselves especially about the definition of small-scale fishermen and their needs in conformity with international law;

2. There should be effective regulation aimed at 'fair distribution' and the protection of the fisherman's interests everywhere in Indonesia and with a 'customized treatment' in certain areas, including building the capacity of the local government to protect small-scale fishermen;

3. The Indonesian Government needs to take into account every single regulation regarding small-scale fisherman to avoid breaking any international law;

4. The policy made must be comprehensive to increase the living standard of the fishing community from the pre-operational, operational and post-operational perspective, starting from the preparation to go a-fishing (for example: availability of boat and catching tool), catching (catching ability, knowledge about fishing season, availability of 'cool box' as a storage) and utilization of the catch (processing, packaging, and marketing);

5. There should be good coordination between the Ministry of Marine Affairs and Fisheries and other related institutions whose mandates revolve around the well-being of fishermen and fisherwomen. 